\title{
EFEK UKURAN, BENTUK DAN KONSENTRASI PARTIKEL PRECIPITATED CALCIUM CARBONATE (PCC) YANG DITAMBAHKAN PADA SIFAT MEKANIK KOMPOSIT KARET ALAM
}

\section{EFFECT OF SIZE, SHAPE AND CONCENTRATION OF PRECIPITATED CALCIUM CARBONATE (PCC) PARTICLES ADDED ON MECHANICAL PROPERTIES OF NATURAL RUBBER COMPOSITES}

\author{
Ihda Novia Indrajati, Indiah Ratna Dewi, Ike Setyorini \\ Balai Besar Kulit, Karet dan Plastik, Yogyakarta \\ Email: ihdanovia@gmail.com
}

\author{
Diterima: 3 Maret 2013 Direvisi:16 April 2013 Disetujui: 15 Juni 2013
}

\begin{abstract}
The objectives of this research was to study the effect of particle size, shape and concentration of PCC on mechanical properties of natural rubber composites, i.e. tensile strength (Ts) and elongation at break (Eb) at original and aging conditions. Two kinds of PCC were used, PCCL (local, size $12 \mu \mathrm{m}$, uncoated) and PCCD (commercial, size 0.03-0.06 $\mu \mathrm{m}$, stearate coated). PCCL was pre-treated by applying stearic acid. PCCLA was characterized with FTIR, TG/DTA thermal analysis, and morphological test using SEM. The loading of PCC were 2.5; 5.0; 7.5; 10.0 and 12.5 phr respectively. Natural rubber composites were compounded using laboratory scale two roll mill. The incorporation of PCCLA or PCCD into rubber matrix increased $T_{s}$ and $E b$. Both $T s$ and Eb initially increased continued up to the maximum point then decreased. The maximum point of Ts and Eb of PCCLA were given on $10 \mathrm{phr}$, while of PCCD were on $10 \mathrm{phr}$ and $5 \mathrm{phr}$ resepectively. PCCLA with its cubical particle shape gave higher Ts and Eb than those PCCD with its needle-like shape, eventhough the particle size was larger. Aging increased tensile and elongation, because of excessive crosslinking. The characeristic of the interfacial adhesion between rubber matrix and PCC particle was estimated by $T s$ value, and proved that the Ts of PCCLA higher than those of PCCD.
\end{abstract}

Keywords: PCC, mechanical properties, natural rubber composites, particle size and shape

\section{ABSTRAK}

Tujuan penelitian ini adalah mempelajari pengaruh ukuran partikel, bentuk dan konsentrasi PCC terhadap sifat mekanik komposit karet alam yang meliputi tegangan putus (Ts) dan perpanjangan putus $(\mathrm{Eb})$ pada kondisi awal dan pengusangan. PCC yang digunakan yaitu PCCL, (produk lokal, ukuran partikel $12 \mu \mathrm{m}$, tanpa pelapis) dan PCCD, (komersial, ukuran partikel 0,03-0,06 $\mu \mathrm{m}$, dilapisi stearat). PCCL diaktivasi menggunakan asam stearat. Karakterisasi PCCLA dilakukan dengan FTIR, analisa termal TG/DTA dan uji morfologi dengan SEM. Konsentrasi PCC yang digunakan berturut-turut 2,5; 5,0; 7,5; 10,0 dan 12,5 phr. Komposit karet alam dibuat menggunakan two roll mill skala laboratorium. Penambahan PCCLA maupun PCCD meningkatkan tegangan putus dan perpajangan putus komposit. Kenaikan konsentrasi PCCLA maupun PCCD dalam matriks karet alam menaikkan tegangan putus hingga maksimum dan kemudian turun. Nilai maksimum tegangan putus dan perpanjangan putus PCCLA berturut-turut diberikan pada konsentrasi $10 \mathrm{phr}$ sedangkan PCCD pada $10 \mathrm{phr}$ dan $5 \mathrm{phr}$. Partikel PCCLA berbentuk kubus memberikan tegangan putus dan perpanjangan putus lebih tinggi daripada PCCD dengan bentuk partikel jarum, meskipun ukuran partikelnya lebih besar. Pengusangan komposit karet alam telah meningkatkan nilai tegangan putus dan perpanjangan putus yang disebabkan oleh proses pembentukan ikatan silang lanjutan pada komposit. Karakteristik adhesi lapisan antar muka matriks karet dan partikel PCC, diestimasi dengan nilai tegangan putusnya, dan terbukti bahwa tegangan putus PCCLA lebih tinggi daripada PCCD.

Kata kunci: PCC, sifat mekanik, komposit karet alam, bentuk dan ukuran partikel 


\section{PENDAHULUAN}

Kekuatan (strength) mekanik merupakan indeks utama pada kinerja material. Secara umum kekuatan mekanik meliputi tegangan putus, kekuatan fleksural, ketahanan pampat tetap, kekuatan sobek dan perpanjangan putus. Kekuatan mekanik pada komposit polimer diharapkan setinggi mungkin untuk memenuhi persyaratan dalam penggunaannya. Faktor-faktor yang mempengaruhi kekuatan mekanik komposit polimer-partikulat antara lain sifat polimer dan bahan pengisi, serta kesesuaian (compatibility) diantara keduanya; bentuk, ukuran, morfologi permukaan dan konsentrasi bahan pengisi; dispersi dan distribusi partikel dalam matriks polimer, serta status lapisan antar muka (interfacial). Muniandy et al. (2012) menyebutkan bahwa sifat tegangan (tensile) komposit berbahan pengisi umumnya diatur oleh dispersi bahan pengisi, ukuran partikel atau luas permukaan spesifik bahan pengisi, dan interaksi karet dengan bahan pengisi. Onyeagoro (2012) dan Mishra and Shimpi (2005) menambahkan geometri bahan pengisi mempengaruhi sifat tegangan putus, dimana geometri yang tidak beraturan dapat menurunkan tegangan putus. Muniandy et.al. (2012) juga melaporkan hal serupa, dimana bahan pengisi dengan aspek rasio tinggi memberikan peningkatan tegangan putus yang signifikan. Lebih lanjut, Muniandy et al. (2012) menjelaskan bahwa luas permukaan yang lebih besar meningkatkan kemampuan partikel bahan pengisi untuk dibasahi (wettability) oleh matrik, oleh karena itu celah mikro yang terbentuk lebih sedikit sehingga interaksi antara karet dengan bahan pengisi akan meningkat dan bahan pengisi dapat menahan beban yang diteruskan dari matriks. Berdasarkan bentuk partikel, bahan pengisi partikulat dibedakan menjadi partikel bola (sphere), lembaran/serpihan (sheet/flaky) dan jarum/kolom (needle/column). Masingmasing jenis partikel tersebut akan memberikan mekanisme penguatan yang berbeda terhadap komposit polimer. Partikel bentuk lembaran/serpihan memberikan efek penguatan yang paling besar, diikuti oleh bentuk jarum dan bola (Liang, 2013).

Analisa komprehensif efek penguatan komposit polimer dapat didekati dengan beberapa teori, dan salah satunya adalah teori adesi lapisan antar muka (interfacial adhesion). Ketika komposit polimer dikenai beban, terutama untuk komposit berbahan pengisi partikulat, maka stress yang diterima oleh matriks dan bahan pengisi diteruskan melalui lapisan diantara keduanya. Oleh karena itu dalam teori penguatan adesi lapisan antar muka diyakini bahwa penguatan komposit dengan bahan pengisi partikulat tergantung pada peningkatan kekuatan adesi lapisan antar muka. Pada kekuatan adesi lapisan antar muka yang sama, semakin besar luas lapisan antar muka bahan pengisi, maka akan semakin baik efek penguatan komposit polimer(Liang, 2013).

Turcsanyi et al. (1988) dalam Liang (2013) memperhitungkan sifat pengisian bahan pengisi anorganik, dan untuk komposit berbahan pengisi partikulat dengan adhesi lapisan antar muka tertentu mengikuti hubungan empiris seperti pada persamaan persamaan(1).

$A R(\%)=\frac{M_{p}}{M_{p}+M_{t}} * 100$

jika $\sigma_{y c}$ dan $\sigma_{y m}$ adalah tegangan putus komposit dan matriks, $\varphi_{f}$ adalah fraksi volum bahan pengisi dan $B$ merupakan parameter yang berkaitan dengan kekuatan adesi lapisan antar muka. Parameter interaksi $(B)$ merupakan parameter empiris yang dapat ditentukan dari hasil penelitian menggunakan data tegangan putus. Jika $B$ kurang dari 1, maka adesi lapisan antar muka bersifat lemah. Jika $B$ berada antara 1 dan 3, bersifat sedang, sedangkan bila $B$ lebih dari 3 bersifat kuat dan tegangan putus akan naik sejalan dengan naiknya fraksi volum bahan pengisi.

Penguatan komposit dengan partikel bahan pengisi menyebabkan kenaikan pada kekakuan (stiffness), yang dihasilkan dari partikel rigid dalam matriks elastomer yang lunak dan dari ikatan silang pada lapisan antar muka partikel-matriks. Derajat penguatan matriks tergantung pada kekuatan interaksi antara fasa bahan organik (matriks) dan bahan anorganik (bahan pengisi). Interaksi antara kedua fasa bahan tersebut terdapat 3 (tiga) macam, yaitu antara polimer dengan bahan pengisi, bahan pengisi dengan bahan pengisi dan polimer-polimer. Sifat bahan pengisi yang 
mempengaruhi sifat mekanik meliputi ukuran partikel, ukuran agregat, morfologi atau struktur dan karakteristik permukaan. Kesesuaian bahan pengisi hanya dapat dicapai jika bahan pengisi tersebut terdispersi dengan baik dalam matriks polimer (Mishra, et al., 2011).

Penambahan bahan pengisi kedalam karet mengubah sifat fisisnya secara signifikan. Secara umum akan terjadi penambahan sifat seperti sifat mekanik, fatigue dan sifat termal (Shimpi and Mishra, 2010). Penelitian tentang komposit polimer dengan bahan pengisi partikulat difokuskan tidak hanya pada pengurangan biaya produksi, namun juga pada peningkatan kekakuan dan kekuatan, stabilitas dimensional dan pencegahan degradasi matriks polimer (Shi,et.al., 2010).

Precipitated calcium carbonate (PCC) merupakan bentuk sintetis dari kalsium karbonat. PCC telah digunakan secara luas sebagai bahan pengisi pada komposit polimer seperti plastik, tekstil, karet, cat, pigmen dan kertas. Penggunaan PCC ditentukan oleh beberapa sifat, seperti morfologi, struktur, ukuran dan distribusi ukuran partikel, karakteristik permukaan dan derajat dispersi (Cheng, et al., 2004, Lam, et al., 2009, Ukrainczyk, et al., 2009). Dispersi partikel PCC dalam matriks polimer merupakan hal penting, terutama jika luas permukaan spesifik PCC besar dengan kecenderungan membentuk aglomerat (Ukrainczyk, et al., 2009) dan tegangan muka yang tinggi (Li, et al., 2010).

Bahan pengisi jenis mineral, seperti PCC, sulit didispersikan secara homogen dalam matrik polimer bila hanya dengan mengandalkan gaya gesek dalam pencampuran lelehan (melt blending). Interaksi partikel bahan pengisi dengan jaringan polimer dapat dimodifikasi dengan perlakuan permukaan menggunakan bahan anorganik (Mishra, et al., 2011). Modifikasi permukaan partikel PCC merupakan cara yang efektif untuk mengurangi tegangan muka dan meningkatkan kesesuaian dengan matriks polimer. Proses tersebut menghasilkan rantai alkil hidrofobik yang terjerap (adsorbed) secara kimiawai pada permukaan mineral, oleh karenanya mempengaruhi gaya permukaan antara bahan pengisi dan matriks polimer (Ukrainczyk, et al., 2009). Sifat dan struktur lapisan tipis bahan organik memberikan pengaruh pada sifat akhir komposit polimer karena lapisan tipis tersebut menunjukkan lapisan antar muka diantara dua bahan yang heterogen.

Asam lemak, umumnya asam stearat, merupakan surfaktan yang umum dipakai untuk memodifikasi partikel PCC. Konsentrasi minimal molekul asam stearat yang dapat memberikan presipitat hidrofobik sangat diperlukan karena surfaktan yang berlebihan dapat menyebabkan penurunan sifat fisikokimia komposit (Ukrainczyk, et al., 2009, Shi et al., 2010). Gilbert (2001) dalam Shi et al. (2010) menyatakan bahwa asam stearat menghasilkan konsentrasi maksimum material organik yang terjerap pada permukaan kalsium karbonat. Menurut Osman and Suter (2002) dalam $\mathrm{Hu}$ et al. (2009) asam stearat bereaksi dengan partikel kalsit dan melapisinya dengan monolayer kalsium stearat bikarbonat. Satu molekul asam bereaksi dengan setiap $\mathrm{Ca}^{2+}$ pada permukaan terlepas dari adanya anion dan rantainya berorientasi vertikal terhadap permukaan. $\mathrm{Hu}$ et al. (2009) juga menyebutkan naiknya konsentrasi asam lemak akan meningkatkan hidrofobisitas PCC.

Tujuan penelitian ini adalah untuk mempelajari pengaruh ukuran, bentuk dan konsentrasi partikel PCC yang ditambahkan terhadap sifat mekanik komposit karet alam yang meliputi tegangan putus, perpanjangan putus dan kekuatan sobek. Pengamatan dilakukan pada kondisi awal dan setelah pengusangan. Komposit karet alam pada percobaan ini menggunakan 2 (dua) jenis PCC dengan ukuran partikel berbeda, yaitu PCC produksi lokal dan PCC komersial. PCC lokal sebelum digunakan terlebih dahulu diaktivasi dengan asam stearat.

\section{BAHAN DAN METODE}

\section{Bahan Penelitian}

Bahan penelitian terdiri atas penyusun kompon dan pengaktivasi PCC. Bahan penyusun kompon teridiri dari karet alam jenis pale crepe yang diperoleh di pasaran, PCC lokal produksi Surabaya (PCCL) dengan 
Tabel 1. Komposisi bahan penyusun kompon

\begin{tabular}{|c|c|c|c|c|c|c|c|c|c|c|c|}
\hline \multirow{2}{*}{ Bahan } & \multicolumn{11}{|c|}{ Kode/Komposisi (phr) } \\
\hline & $\mathrm{K}$ & D1 & D2 & D3 & D4 & D5 & L1 & L2 & L3 & L4 & L5 \\
\hline NR & 100 & 100 & 100 & 100 & 100 & 100 & 100 & 100 & 100 & 100 & 100 \\
\hline $\mathrm{ZnO}$ & 5 & 5 & 5 & 5 & 5 & 5 & 5 & 5 & 5 & 5 & 5 \\
\hline $\begin{array}{l}\text { Aflux } 42 \\
\text { A }\end{array}$ & 1 & 1 & 1 & 1 & 1 & 1 & 1 & 1 & 1 & 1 & 1 \\
\hline PCCD & 0 & 2,5 & 5 & 7,5 & 10 & 12,5 & 0 & 0 & 0 & 0 & 0 \\
\hline PCCL & 0 & 0 & 0 & 0 & 0 & 0 & 2,5 & 5 & 7,5 & 10 & 12,5 \\
\hline HAF & 30 & 30 & 30 & 30 & 30 & 30 & 30 & 30 & 30 & 30 & 30 \\
\hline GPF & 25 & 25 & 25 & 25 & 25 & 25 & 25 & 25 & 25 & 25 & 25 \\
\hline TMQ & 1 & 1 & 1 & 1 & 1 & 1 & 1 & 1 & 1 & 1 & 1 \\
\hline 6PPD & 2 & 2 & 2 & 2 & 2 & 2 & 2 & 2 & 2 & 2 & 2 \\
\hline $\begin{array}{l}\text { Antilux } \\
654\end{array}$ & 1 & 1 & 1 & 1 & 1 & 1 & 1 & 1 & 1 & 1 & 1 \\
\hline $\begin{array}{l}\text { Paraffinic } \\
\text { oil }\end{array}$ & 10 & 10 & 10 & 10 & 10 & 10 & 10 & 10 & 10 & 10 & 10 \\
\hline MBTS & 1,0 & 1,0 & 1,0 & 1,0 & 1,0 & 1,0 & 1,0 & 1,0 & 1,0 & 1,0 & 1,0 \\
\hline DPG & 0,25 & 0,25 & 0,25 & 0,25 & 0,25 & 0,25 & 0,25 & 0,25 & 0,25 & 0,25 & 0,25 \\
\hline PVI & 0,1 & 0,1 & 0,1 & 0,1 & 0,1 & 0,1 & 0,1 & 0,1 & 0,1 & 0,1 & 0,1 \\
\hline Peptizer & 0,5 & 0,5 & 0,5 & 0,5 & 0,5 & 0,5 & 0,5 & 0,5 & 0,5 & 0,5 & 0,5 \\
\hline Sulfur & 1 & 1 & 1 & 1 & 1 & 1 & 1 & 1 & 1 & 1 & 1 \\
\hline
\end{tabular}

ukuran partikel $12 \mu \mathrm{m}$ (uncoated), PCC DiACAL CC (PCCD) dengan ukuran partikel 0,03-0,06 $\mu \mathrm{m}$ (stearate coated), High Abrasion Furnace (HAF) Black Ex.OCI, General Purpose Furnace (GPF) Black Ex.Korea, Paraffinic oil, polimer 2,2,4Trimethyl-1,2-Dihydroquinoliner (TMQ) Ex.Kemai, Paraffin wax Antilux 654A, ZnO (Bratachem), Aflux $42 \mathrm{M}, N-(1,3-$ dimethylbutyl) - $N^{\prime}-p h e n y l-p$ phenylenediamine (6PPD) Ex.Northeast, 2,2'Dithiobis(benzothiazole) (MBTS) Ex.Shandong Sianxian, $N, N^{\prime}$-Diphenyl guanidine (DPG) Ex.Shandong Sianxian, Sulfur SP-325 Ex.Miwon, Prevulcanization Inhibitor (PVI) dan Peptizer Aktiplast 8. Bahan pengaktivasi meliputi asam sterat (komersial), etanol 95\% dan akuades. Komposisi bahan-bahan tersebut dalam kompon disajikan pada Tabel 1.

\section{Peralatan Penelitian}

Peralatan meliputi two roll mill skala laboratorium, hidrolik press, alat uji tegangan putus. Peralatan yang digunakan pada proses aktivasi antara lain gelas beaker, pengaduk magnetis, oven dan corong pisah, sedangkan karakterisasi partikel PCCL hasil aktivasi digunakan FTIR (Shimadzu), TG/DTA
(Perkin-Elmer) dan SEM (JEOL-JSM6510LV).

\section{Cara Penelitian}

Aktivasi PCC Lokal (PCCL)

PCCL diaktivasi terlebih dahulu sebelum digunakan dengan cara sebagai berikut: PCCL dipanaskan pada suhu $50^{\circ} \mathrm{C}$ selama 3 jam dalam oven sebagai perlakuan pendahuluan. Sebanyak 30 gram PCCL hasil pemanasan, $40 \mathrm{~mL}$ alkohol dan $9 \mathrm{~g}$ asam stearat dimasukkan dalam gelas beaker, selanjutnya diaduk dengan kecepatan $400 \mathrm{rpm}$ pada suhu $75^{\circ} \mathrm{C}$ selama 2 jam. Pada akhir waktu aktivasi, fase cair dipisahkan dari sampel melalui penyaringan dan dibilas dengan aquades. Sampel padat yang diperoleh dikeringkan pada suhu $100^{\circ} \mathrm{C}$ selama 3 jam untuk menghilangkan air terikat. Efek modifikasi permukaan dievaluasi melalui rasio aktif(AR) yang dihitung dengan metode floating test (Yoğurtcuoğlu and Uurum, 2011). Tes tersebut dilakukan sebanyak 15 kali pada formulasi yang sama untuk mengecek reproducibility proses aktivasi, diperoleh ratarata rasio aktif dari 15 kali ulangan adalah $92,25 \%$.

PCCL aktif (PCCLA) dikarakterisasi meliputi analisa sifat morfologi partikel 
digunakan metode SEM, karakteristik gugus fungsi di permukaan partikel digunakan metode FTIR pada panjang gelombang 4000 sampai dengan $600 \mathrm{~cm}^{-1}$ dan analisa termal digunakan metode TG/DTA untuk mengetahui sifat lapisan stearat pada permukaan partikel PCCL.

\section{Pembuatan Kompon dan Pengujian Sifat Mekanik}

Bahan-bahan komponding dicampur menggunakan two roll mill skala laboratorium. Kematangan kompon diuji dengan alat Oscillating Disc Rheometer (ODR). Vulkanisat untuk contoh uji dibuat dengan alat cetak kempa pada tekanan 150 $\mathrm{kg} / \mathrm{cm}^{2}$ dan suhu $150^{\circ} \mathrm{C}$. Pengujian sifat mekanik meliputi tegangan putus dan perpanjangan putus dilakukan menggunakan tensile tester dalam kondisi awal (sebelum pengusangan) dan setelah pengusangan. Pengusangan dilakukan menggunakan airaging oven pada temperatur $70^{\circ} \mathrm{C}$ selama 70 jam. Pengujian dilakukan sebanyak 3 (tiga) kali ulangan.

\section{HASILDAN PEMBAHASAN}

\section{Aktivasi PCC Lokal}

PCCL, PCCLA dan PCCD diuji gugus fungsinya dengan metode FTIR dan pita serapannya ditunjukkan pada Gambar 1. Pita serapan ketiga jenis PCC menunjukkan puncak khas kalsium karbonat yaitu pada panjang gelombang 1434, $877 \mathrm{dan} 711 \mathrm{~cm}^{-1}$.

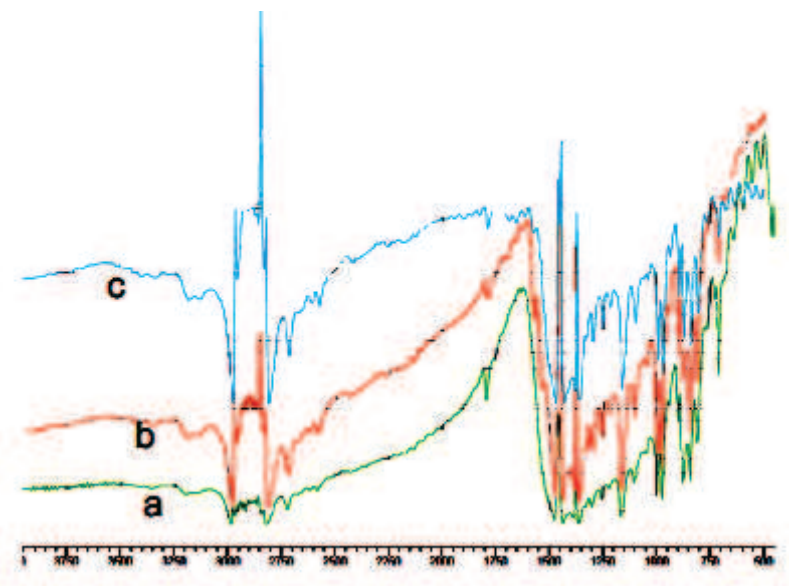

Gambar 1. Spektra FTIR, (a) PCCL awal, (b) PCCLAktif, (c) PCCD
Puncak pada panjang gelombang $2550 \mathrm{~cm}^{-1}$ menunjukkan eksistensi anion $\mathrm{CO}_{3} \mathrm{H}^{-}$pada permukaan partikel PCC. Ditemukan pula puncak pada daerah panjang gelombang 2999 dan $2825 \mathrm{~cm}^{-1}$ yang merupakan spektrum ulur $\mathrm{C}-\mathrm{H}$ asimetris dan simetris dari gugus alkil stearat. Intensitas kedua panjang gelombang tersebut pada spektra PCCL aktif (b) dan PCCD (c) meningkat daripada PCCL awal (a), ditunjukkan dengan puncak yang tajam. Puncak pada panjang gelombang $1600 \mathrm{~cm}^{-1}$ merupakan pita serapan garam karboksilat. Ketiga puncak panjang gelombang tersebut merupakan indikator adanya molekul stearat pada permukaan PCC. Hasil serupa dilaporkan pula oleh Ukrainzcyk et al. (2009), $\mathrm{Li}$, et al, (2010), Donate-Robles and MartinMartinez(2011).

Konsentrasi stearat yang terjerap pada permukaan partikel PCC ditentukan oleh penurunan berat (weight loss) dalam percobaan TGA. Kurva TG/DTG hasil analisa termal terhadap PCCL aktif dipaparkan pada Gambar 2.

Pada analisis TG (kurva a dan b), maka kurva b menunjukkan dekomposisi (terjadi penurunan berat) pada kisaran suhu $200-400^{\circ} \mathrm{C}$ yaitu ditengarai oleh puncak pada suhu $263^{\circ} \mathrm{C}$ pada kurva DTG(c). Menurut Ukrainczyk et al. (2009) dekomposisi pada kisaran tersebut merupakan penghilangan stearat yang terjerap. Shi et al. (2010) menyebutkan bahwa puncak dekomposisi asam stearat normalnya ditemukan pada suhu $220^{\circ} \mathrm{C}$, sedangkan Donate-Robles and Martín Martínez (2011)

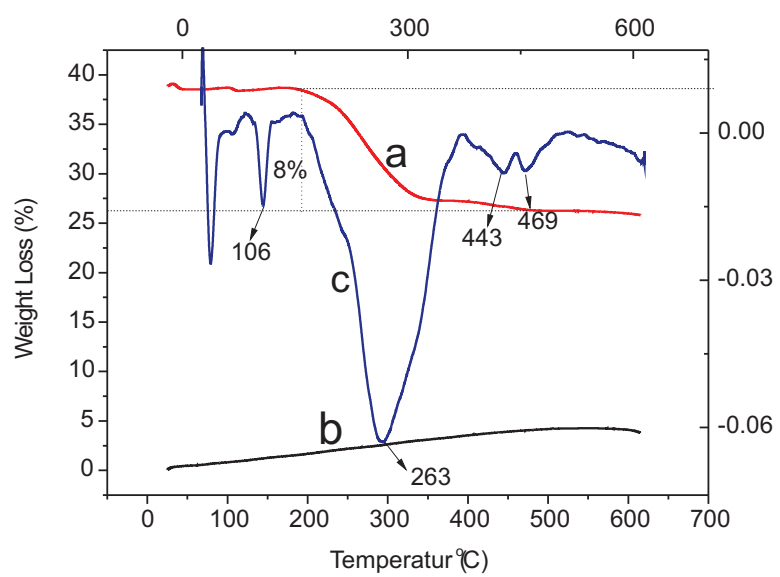

Gambar 2. Kurva (a) TG PCCLA, (b) TG PCCL, (c) DTG PCCLA 
menyebutkan dekomposisi asam stearat terjadi pada $248^{\circ} \mathrm{C}$. Hal tersebut dikonfirmasi oleh hasil analisis TG bahwa dekomposisi pada kisaran suhu $200-400^{\circ} \mathrm{C}$ menunjukkan keberadaan molekul stearat pada permukaan partikel PCCLA. Puncak pada suhu $106^{\circ} \mathrm{C}$ diindikasikan oleh molekul stearat saling mengalami penggabungan (intercelated), termasuk juga molekul stearat bebas dalam jangkauan (coverage) lapisan jamak (Li, et al., 2010). Puncak dekomposisi pada suhu $443^{\circ} \mathrm{C}$ dan $469^{\circ} \mathrm{C}$ merupakan dekomposisi dari kalsium stearat (Moreira, et al., 2009), hasil dari reaksi molekul stearat dengan ion $\mathrm{Ca}^{2+}$ dari kalsium karbonat sesuai dengan reaksi pada persamaan (3) (Yoğurtcuoğlu, and Uurum, 2011).

$\mathrm{CaCO}_{3}+2 \mathrm{C}_{17} \mathrm{H}_{33} \mathrm{COOH} \rightarrow\left(\mathrm{C}_{17} \mathrm{H}_{33} \mathrm{COO}\right)_{2} \mathrm{Ca}+\mathrm{H}_{2} \mathrm{CO}_{3}$

Morfologi partikel PCCL aktif dan PCCD hasil foto SEM disajikan pada Gambar 3.

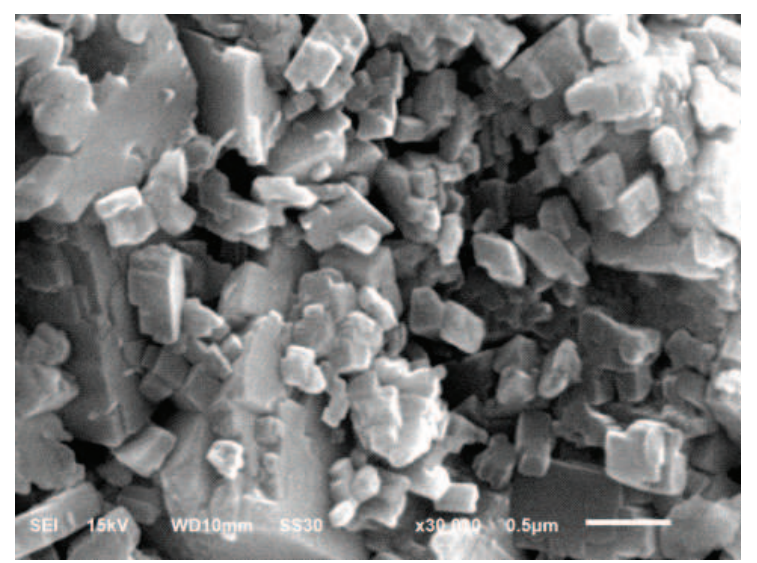

(a)

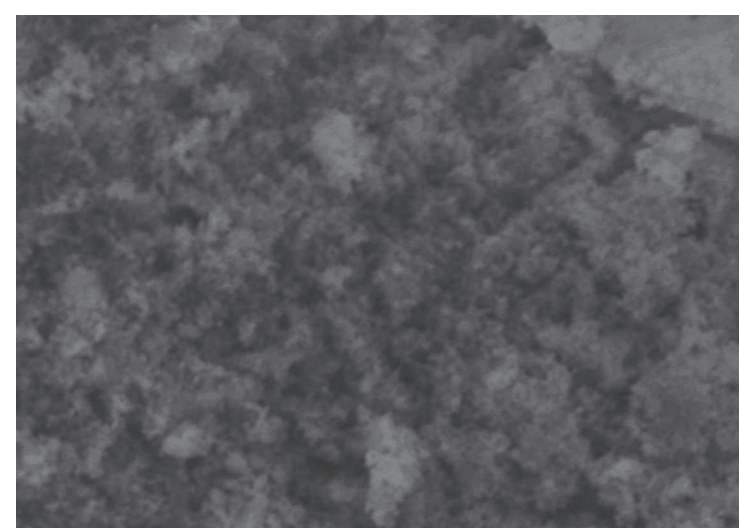

(b)

Gambar 3. Morfologi partikel (a) PCCL, (b) PCCD
Bentuk partikel PCCL ditunjukkan pada Gambar 3a adalah bentuk kubus atau lembaran, sedangkan PCCD (Gambar 3b) partikelnya berbentuk jarum.

\section{Tegangan Putus}

Tegangan putus vulkanisat dengan PCCLA lebih tinggi daripada PCCD pada konsentrasi 2,5; 10 dan 12,5 phr, seperti ditunjukkan oleh Gambar 4. Sedangkan pada konsentrasi 5 dan 7,5 phr memberikan nilai yang sebanding yaitu pada kisaran $13 \mathrm{MPa}$. Menurut $F u$, et al. (2008) ukuran partikel mempunyai efek yang signifikan pada kekuatan komposit polimer dengan bahan pengisi partikulat, dimana umumnya akan naik dengan turunnya ukuran partikel. Hasil penelitian menunjukkan kecenderungan yang berbeda dengan pernyataan tersebut, dimana ukuran partikel PCCLA lebih besar daripada PCCD.

Untuk menjawab fenomena tersebut perlu dikaji pengaruh bentuk atau geometri partikel PCC terhadap mekanisme penguatan (reinforcement). Hasil uji morfologi (Gambar 3) menunjukkan kedua jenis partikel PCC mempunyai bentuk yang berbeda, dimana partikel PCCLA berbentuk kubus, sedangkan PCCD berbentukjarum.

Pada kekuatan adhesi lapisan antar muka yang sama, semakin besar luas lapisan antar muka bahan pengisi, maka semakin baik efek penguatan komposit. Apabila dispersi bahan pengisi di dalam matriks polimer homogen, maka luas permukaan lapisan antar muka setara dengan konsentrasi luas

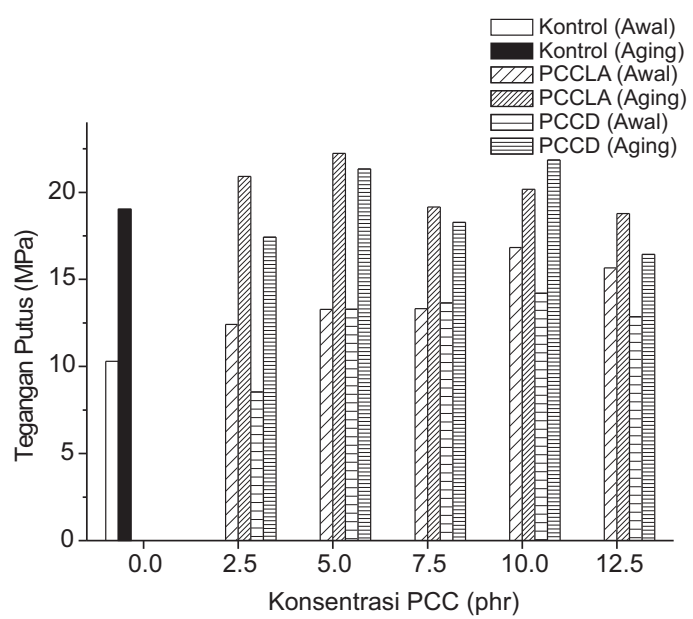

Gambar 4. Tegangan putus komposit pada berbagai konsentrasi 
permukaan partikel bahan pengisi. Luas permukaan partikel kubus/lembaran lebih besar daripada partikel jarum (Liang, 2013).

Mekanisme transfer stress partikel kubus terjadi melalui lapisan antar muka diantara keempat sisi samping bahan pengisi dan matriks, dan lapisan antar muka paralel dengan arah beban tegangan. Transfer stress yang terjadi melalui lapisan antar muka permukaan atas dan bawah partikel adalah tegak lurus terhadap arah beban tegangan dan matriks. Sedangkan pada partikel jarum, jika berorientasi sepanjang arah beban tegangan maka stress akan ditransfer melalui lapisan antar muka diantara sisi samping partikel dan matriks. Lapisan antar muka paralel dengan arah beban tegangan. Transfer stress pada permukaan atas dan bawah tegak lurus terhadap arah beban tegangan dan matriks. Sehingga sifat fisis dan mekanik komposit dengan bahan pengisi partikulat bentuk jarum bersifat anisotrop. Mekanisme transfer stress pada komposit partikulat bentuk kubus/lembaran dan jarum adalah sama bila kedua partikel berorientasi yang sama terhadap arah beban tegangan. Perbedaan terletak pada luas permukaan kedua bentuk partikel. Partikel kubus memberikan luas permukaan yang lebih besar, sehingga luas lapisan antar muka matriks/bahan pengisi yang diberikan pun besar. Oleh karenanya efek penguatan yang diberikan partikel kubus/lembaran terhadap matriks karet juga lebih besar (Liang, 2013). Penjelasan tersebut memberikan gambaran bahwa PCCLA dengan ukuran partikel lebih besar memberikan tegangan putus lebih tinggi daripada PCCD.

Penambahan PCCLA maupun PCCD secara umum meningkatkan tegangn putus dibanding dengan kontrol. Namun, pada PCCD 2,5 phr memberikan nilai lebih rendah. Bertambahnya konsentrasi PCCLA meningkatkan tegangan putus hingga mencapai nilai maksimum pada 10 phr. Meningkatnya tegangan putus, menurut Ahmed et.al. (2013), merupakan kontribusi dari interaksi antara bahan pengisi dengan molekul karet. Permukaan partikel PCC kontak dengan molekul karet alam menghasilkan batasan yang efektif terhadap pergerakan rantai molekul dengan meningkatkan ikatan lapisan antar muka, sehingga rantai molekul tidak bebas bergerak saat dikenai beban (Soundararajah, et al., 2009). Interaksi tersebut berperan penting dalam meningkatkan tegangan putus. PCC sebagai bahan pengisi anorganik dapat bertindak sebagai nucleating agent bagi karet alam yang bersifat kristalin. Bila matriks karet alam dikenai beban, PCC dapat memperbaiki struktur kristal dan derajat kristalisasi karet alam, sehingga akan menaikkan tegangan putus. Penambahan PCCLA lebih lanjut hingga 12,5 phr menurunkan tegangan putus. Konsentrasi partikel bahan pengisi yang semakin banyak memperbesar interaksi diantara partikel tersebut yang mengarah pada pembentukan aglomerat. Aglomerasi menyebabkan komposit tidak homogen secara struktural dan pada level stress tertentu dapat terlepas dari matriks, mengarah pada timbulnya retakan yang dapat menginisasi timbulnya patahan. Konsentrasi PCC semakin besar maka jumlah maksimum PCC yang dapat ditambahkan dalam polimer semakin terdekati dan kemungkinan terjadinya diskontinyuitas matriks akan meningkat. Diskontinyuitas matriks dalam bentuk apapun akan menginisiai timbulnya patahan. PCCD menunjukkan fenomena yang sama dengan PCCLA, hanya pada konsentrasi 2,5 phr memberikan tegangan putus lebih rendah daripada kontrol.

Pengusangan meningkatkan tegangan putus komposit (Gambar 4) untuk kedua jenis PCC pada berbagai konsentrasi. Kenaikan tersebut disebabkan adanya pembentukan ikatan silang lanjutan pada saat proses pengusangan, mengingat sistem vulkanisasi yang dipakai adalah efisien (EV), dimana kerapatan ikatan silang akan bertambah dengan pemanasan lanjut. PCCLA memberikan tegangan putus komposit lebih tinggi daripada PCCD kecuali pada 10 phr. Konsentrasi PCC dalam komposit setelah pengusangan memberikan pola tegangan putus yang tidak beraturan, maka dapat dikatakan konsentrasi PCC tidak mempengaruhi tegangan putus setelah pengusangan.

\section{Perpanjangan Putus}

Perpanjangan putus (Gambar 5) pada 
kondisi awal komposit karet alam dengan PCCLA sebagai bahan pengisi meningkat hingga konsentrasi 10 phr dan kemudian turun pada 12,5 phr. Pola serupa juga ditunjukkan oleh komposit berbahan pengisi PCCD. Shimpi and Mishra (2010) melaporkan hal yang sama. Namun peneliti lain (Onyeagoro, 2012; Ahmed, et al., 2013) menyatakan bahwa perpanjangan putus komposit karet alam turun dengan naiknya konsentrasi bahan pengisi sebagai akibat meningkatnya kekakuan dan kerapuhan (brittleness) yang menurunkan ketahanan mulur (strecth) dengan adanya regangan. Penambahan PCCLA maupun PCCD kedalam matriks karet alam meningkatkan perpanjangan putus dibanding dengan kontrol.

Kenaikan perpanjangan putus (Gambar 5) hingga nilai maksimum mengindikasikan bahwa interaksi antara partikel PCC dengan molekul karet terjadi dengan baik. Kenaikan konsentrasi PCC lebih tinggi menyebabkan penurunan perpanjangan putus karena jumlah PCC yang tinggi membatasi kemampuan matriks untuk dapat mulur diantara partikelpartikel PCC, dan pelepasan partikel PCC dari matriks menyebabkan kavitasi. Pada konsentrasi PCC tinggi muncul agregat sebagai akibat interaksi antara partikelpartikel PCC, disamping interaksi antara partikel PCC dengan matriks karet alam. Agregat membentuk lebih banyak daerah dengan interaksi antar muka yang lemah antara permukaan PCC dan matriks karet alam. Retakan akan berjalan dengan mudah melalui daerah tersebut, sehingga komposit

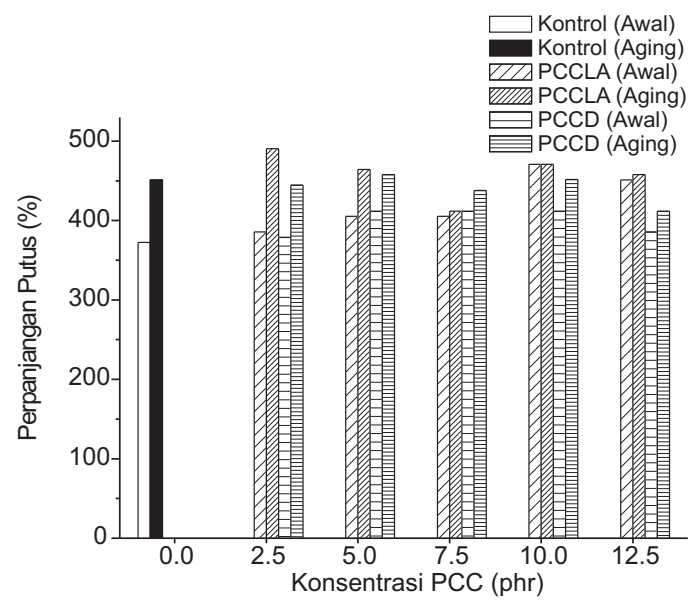

Gambar 5. Perpanjangan putus (a) awal, (b) pengusangan patah pada derajat perpanjangan yang rendah ( $\mathrm{A} \mathrm{h} \mathrm{m} \mathrm{e} \mathrm{d,} \mathrm{e} \mathrm{t} \mathrm{a} \mathrm{l.,} 2013$ ). Pada konsentrasi 2,5; 10 dan 12,5 phr, komposit dengan PCCLA memberikan perpanjangan putus lebih tinggi daripada komposit dengan PCCD. Sedangkan pada konsentrasi 5 dan $7,5 \mathrm{phr}$ nilainya sedikit berada dibawah PCCD. Partikel PCCLA (Gambar 3a) berbentuk kubus/lembaran tidak membuat komposit menjadi rigid. Pada gaya tegangan, partikel kubus/lembaran dapat saling bergeser (sliding) satu sama lain, sehingga menghasilkan persentase perpanjangan putus lebih tinggi (Muniandy, et al., 2012). Perpanjangan putus maksimum komposit dengan PCCLA (470,8\%) dicapai pada konsentrasi 10 phr. Sedangkan komposit dengan PCCD mencapai maksimum pada konsentrasi 5 phr yaitu $411,8 \%$, dan konsentrasi 7,5 dan 10 phr juga memberikan nilai yang sama.

Pengusangan komposit secara umum meningkatkan perpanjangan putus untuk kedua jenis PCC seperti diilustrasikan pada Gambar 5. Hal ini dapat dijelaskan karena pemanasan pada proses pengusangan menyebabkan terjadinya pembentukan ikatan silang lanjut, sehingga kerapatannya meningkat. Oleh karenanya perpanjangan putus pun turut meningkat nilainya.

\section{Karakterisasi Adhesi Lapisan Antar Muka}

Parameter $B$ dapat diestimasi menggunakan data tegangan putus, dihitung menggunakan persamaan (1), hasilnya diilustrasikan pada Gambar 6.

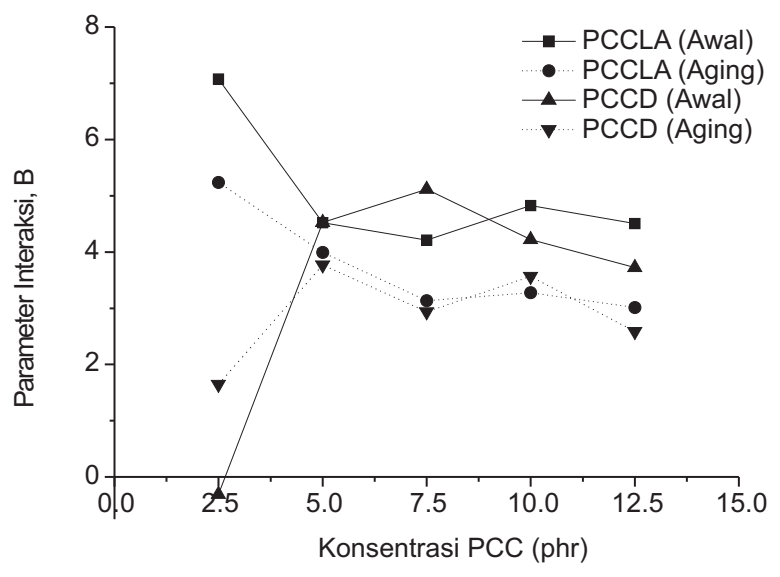

Gambar 6. Parameter interakasi (B), (a) awal (sebelum pengusangan), (b) pengusangan 
Komposit dengan PCCLA mempunyai nilai $\mathrm{B}>3$ pada semua konsentrasi, sedangkan PCCD nilai $\mathrm{B}>3$ dicapai pada konsentrasi 5 12,5 phr. Hal tersebut berarti adhesi lapisan antar muka PCCLA maupun PCCD dengan matriks karet alam bersifat kuat. Sedangkan pada PCCD 2,5 phr diperoleh nilai $\mathrm{B}<1$, yang artinya adhesi bersifat lemah. Parameter interaksi PCCLA lebih tinggi daripada PCCD (Gambar 6a), artinya pada konsentrasi yang sama PCCLA memberikan adhesi lapisan antara yang lebih kuat daripada PCCD. Nilai B dipengaruhi juga oleh geometri partikel bahan pengisi (Pukánzy, 1990). Partikel PCCD memiliki geometri yang anisotropi dimana interaksi akan bergantung pada arah atau sumbu, sehingga akan terjadi perbedaan kekuatan interaksi. Berbeda dengan partikel PCCLA yang bersifat isotrop, dimana interaksi mempunyai sifat yang sama pada semua arah atau sumbu. Pukánzy (1990) juga menyatakan bahwa tegangan putus bergantung pada geometri bahan pengisi. Hal tersebut mengkonfirmasi nilai tegangan putus (Gambar 4) PCCL aktif lebih tinggi daripada PCCD pada konsentrasi yang sama. Pengusangan menurunkan nilai $B$, sebaliknya pada PCCD 2,5 phr. Penurunan tersebut mengindikasikan melemahnya adhesi lapisan antar muka, yang dapat mengarah pada lepasnya partikel PCC dari matriks karet alam. Namun, tegangan putus komposit (dengan kedua jenis PCC) setelah pengusangan justru meningkat, maka melemahnya adhesi lapisan antara belum memberikan efek yang signifikan. Sehingga dapat dikatakan kenaikan tegangan putus setelah pengusangan terutama akibat adanya pembentukan ikatan silang lanjutan.

\section{KESIMPULAN}

Aktivasi PCC lokal dengan asam stearat sebagai langkah pendahuluan berhasil baik dengan masuknya gugus stearat pada permukaan PCC seperti ditunjukkan pada spektra FTIR. Konsentrasi stearat yang menempel dianalisa dengan metode TG/DTA ditunjukkan sebesar $8 \%(\mathrm{~b} / \mathrm{b})$. Uji SEM terhadap morfologi partikel PCCLA menunjukkan bentuk kubus/lembaran, sedangkan partikel PCCD berbentuk jarum. Penambahan PCCLA maupun PCCD meningkatkan tegangan putus dan perpanjangan putus komposit karet alam. Nilai maksimum diberikan pada konsentrasi PCCLA 10 phr dan PCCD. 5 phr. PCCLA dengan ukuran partikel lebih besar memberikan tegangan putus dan perpanjangan putus lebih tinggi karena bentuk partikelnya isotropik sehingga memberikan interaksi yang baik dengan matriks karet alam. Konsentrasi PCCLA maupun PCCD dalam matriks karet alam tidak mempengaruhi tengangan putus dan perpanjangan putus setelah pengusangan. Kenaikan kedua parameter tersebut disebabkan pembentukan ikatan silang akibat pemanasan lanjut. Parameter interaksi $(B)$ diestimasi menggunakan data tegangan putus, dimana komposit karet alam dengan PCCLA maupun PCCD memberikan nilai $B>3$ kecuali pada PCCD 2,5 phr, maka interaksi matriks karet alam dan bahan pengisi bersifat kuat. Pada konsentrasi yang sama, PCCLA memberikan nilai $\mathrm{B}$ yang lebih tinggi daripada PCCLD, disebabkan sifat anisotropi geometeri PCCD.

\section{UCAPAN TERIMA KASIH}

Proyek penelitian ini dilaksanakan oleh tim kelompok kerja 1866.001.002.023 yang didanai oleh DIPA Balai Besar Kulit, Karet dan Plastik tahun anggaran 2012. Penulis mengucapkan terima kasih pada seluruh anggota tim. Ucapan terima kasih ditujukan pada Bapak Eka Budiman (PT. Suryaraya Rubberindo Industry) atas bantuannya dalam penggunaan fasilitas Rheometer.

\section{DAFTAR PUSTAKA}

Ahmed, K., Nizami, S.S., Raza, N. Z. and Mahmood, K., 2013. Effect of microsized marble sludge on physical properties of natural rubber composite, Chemical Industry \& Chemical Engineering Quarterly, 19(2): 281-293.

Cheng, B., Lei, M., Yu, J. and Zhao, X., 2004. Preparation of monodispersed cubic calcium carbonate particles via precipitation reaction, Material Letters, 58: 1565-1570.

Donate-Robles, J. and Martin-Martinez, J. M., 2011. Addition of precipitated calcium carbonate filler to thermoplastic polyurethane adhesives, International 
Journal of Adhesion and Adhesive, 31: 975-804.

Fu, S-Y., Feng, X-Q, Lauke. B. and Mai, Y-M., 2008. Effect of particle size, particle/matrix interface adhesion and particle loading on mechanical properties of particulate-polymer composites, Composites Part B: Engineering, 39: 9333-961

Hu, Z., Zen, X., Gong, J. and Deng, Y., 2009. Water resistance improvement of paper by superhydrophic modification with microsized $\mathrm{CaCO}_{3}$ and fatty acid coating, Colloid and Surface A: Physicochemical and Engineering Aspects, 351:65-70.

Lam, T. D., Hoang, T. V., Quang, D. T. and Kim, J. S., 2009. Effect of nanosized and surface-modified precipitated calcium carbonate on properties of $\mathrm{CaCO}_{3} /$ polypropylene nanocomposites, Materials Science and Engineering. A, 501:87-93

Li, Y., Zhao, Z., Lau, Y. R., Lin, Y. and Chan, C., 2010 , Preparation and characterization of coverage-controlled $\mathrm{CaCO}_{3}$ nanoparticles, Journal of Colloid and Interface Science, 345: 168-173

Liang, J. Z., 2013. Reinforcement and quantitative description of inorganic particulate-filled polymer composites, Composites: Part B, 51:224-232

Mishra, S., Shimpi, N. G. and Mali, A. D., 2011. Influence of stearic acid treated nano- $\mathrm{CaCO}_{3}$ on the properties of silicone nanocomposites, Journal of Polymer Research, 18: 1715-1724

Mishra, S. and Shimpi, N. G., 2005. Mechanical properties of flameretardant properties of styrenebutadiene rubber filled with $\mathrm{CaCO}_{3}$ and linseed oil as an extender, Journal of Applied Polymer Science, 25: 25632571

Moreira, A.P.D., Souza, B. S., Teixera, A. M. R. F., 2009, Monitoring of calcium ste a rate formation by thermogravimetry, Journal of Thermal Analysis and Calorimetry, 97: 647-652
Muniandy, K., Ismail, H. and Othman, N., 2012. Effect of partial replacement of rattan powder by commercial fillers on the properties of natural rubber composites, BioResources, 7(4): 46404657.

Onyeagoro, N., 2012. Cure characteristic and physico-mechanical properties of carbonized bamboo fibre filled natural rubber vulcanizates, International Journal of Modern Engineering Research, 2(6): 4683-4690.

Pukánzy, B., 1990. Influence of interface interaction on the ultimate tensile properties of polymer composites, Composite, 21(3): 255-262.

Shi, X., Rosa, R. and Lazzeri, A., 2010. On the coating of precipitated calcium carbonate with stearic acid in aqueous medium, Langmuir, 26 (11): 8474-8482.

Shimpi, N. G. and Mishra, S., 2010. Synthesis of nanoparticles and its effect on properties of elastomeric nanocomposites, Journal of Nanoparticle Research, 12: 2093-2099.

Soundararajah, Q. Y., Karunaratne, B. S. B. and Rajapakse, R. M. G., 2009. Montmorillonite polyaniline nanocomposites: preparation, characterization and investigation of mechanical properties, Materials Chemistry and Physics, 113: 850-855.

Ukrainczyk, M., Kontrec, J. and Kralj, D., 2009. Precipitation of different calcite crystal morphologies in the presence of sodium stearate, Journal of Colloid Interface Science, 329: 89-96.

Yoğurtcuoğlu, E. and Uurum, M., 2011. Surface modification of calcite by wetstirred ball milling and its properties, Powder Technology, 214: 47-53. 